\title{
Michael Reisman, Dean of the New Haven School of International Law
}

\author{
Harold Hongju Koh ${ }^{\dagger}$
}

I am Dean of the Yale Law School. I like to think of myself as Michael Reisman's "other Harold." His first Harold was, of course, the great political scientist Harold Lasswell who, along with Myres McDougal, founded the New Haven School of International Law. But for nearly twenty-five years, Michael Reisman has also been my senior colleague, and by osmosis, my teacher, as we have served together on the Yale Law School faculty. I like to think that he has granted me, a lifelong New Havener, admission as a "special student" in the New Haven School of International Law. That is an intellectual school in which I have been a fellow traveler and of which Michael has been the acknowledged Dean. And so, the irony: while I have been his "other Harold," Michael has been my "other Dean!"

All of us - the scholars, international lawyers, and students gathered at this Conference-gather today to celebrate four remarkable attributes of "Dean" Michael Reisman. The first is that Michael has been a scholar of stunning achievement and range. He is just astonishingly prolific and incisive. Trying to read all his work, in public and private international law, jurisprudence, and human rights, inevitably makes one feel inadequate. Michael Reisman can write faster than most scholars can read. Like a man bailing out a leaky boat, by the time you fill up one bucket, you find that five more buckets full have poured in! There is almost no way to read Michael's huge scholarly corpus seriatim. So over the years, what I have learned to do instead, whenever I come across a new topic in international law-whether corruption, prodemocracy intervention, review and enforcement of international judgments, treaty interpretation, or communications theory-is to look first for what Michael has written on the subject. He has always written something cogent. And every piece is elegant, powerful, and insightful, and gives me a new clarifying lens with which to view the subject.

More fundamentally, as we will hear in the panels in today's conference, Michael Reisman fundamentally transformed the New Haven School of International Law. As I have noted elsewhere, during the founding era of Myres McDougal and Harold Lasswell, the New Haven School was the

$\dagger \quad$ Dean and Gerard C. \& Bernice Latrobe Smith Professor of International Law, Yale Law School; Legal Adviser-Designate, U.S. Department of State. This Essay is a lightly edited and footnoted version of introductory remarks made at "Realistic Idealism in International Law: A Conference in Honor of W. Michael Reisman," held at the Yale Law School on April 24, 2009. It derives in good measure from an essay previously published in this journal, which considered the relationship of the traditional New Haven School of Intemational Law to recent developments in intemational legal theory, which some have dubbed the "New New Haven School of International Law." See Harold Hongju Koh, Commentary, Is There a "New" New Haven School of International Law?, 32 YALE J. INT'L L. 559 (2007). 
international law school for legal realists.' The School developed a functional critique of both legal formalism and legal positivism in international law. Like most schools, the New Haven School did not include all international lawyers who lived in New Haven, nor did all of its members ever reside there. ${ }^{2}$ Today, McDougal's and Lasswell's insights continue to be developed through the work of a diverse array of scholars, many of whom reassemble here today, who share the School's process methodology while adopting a variety of views regarding law's social ends and policy values.

At the same time, however, the New Haven School employed its legal realist methods to critique Cold War political realism, offering, in one scholar's words, "a kind of socio-legal realism to combat the power-based realism that dominated the early Cold War period." McDougal and Lasswell found that the school of political realism both "underestimates the role of rules, and of legal processes in general, and overemphasizes the importance of naked power." Unlike the political realists, the New Haven School insisted on an abiding belief that, even in international affairs, law and rules do matter.

In a lifetime of work, Michael Reisman gave the New Haven School new insights and brought it into the twenty-first century. As great as McDougal was, it was Michael who gave the New Haven School its modern relevance and vitality. As we will hear, his technique has been fundamentally jurisprudential. Michael brilliantly argued that the New Haven School viewed international law as a "process of communication," which sees the legal process as comprising three communicative streams: "policy content, authority signal and control intention." ${ }^{5}$ This communications model, he argued, "liberates the inquirer from the ... distorting model of positivism, which holds that law is made by the legislature," in favor of the notion that "any communication between elites and politically relevant groups which shapes wide expectations about appropriate future behavior must be considered as functional lawmaking."

As fundamentally, under Michael's "deanship," the New Haven School recommitted itself to normative values. By treating international law as more

1. See Koh, supra note $\dagger$, at 561 .

2. As one student of the School put it:

The New Haven school does not describe the world's different community decision processes through a dichotomy of national and international law, in terms of the relative supremacy of one system of rules or other interrelations of rules. Instead, it describes them in terms of the interpenetration of multiple processes of authoritative decision of varying territorial compass. ... [I]nternational law is most realistically observed, not as a mere rigid set of rules but as the whole process of authoritative decision in which patterns of authority and patterns of control are appropriately conjoined.

Eisuke Suzuki, The New Haven School of International Law: An Invitation to a Policy-Oriented Jurisprudence, I YALE J. WORLD PUB. ORD. 1, 30 (1974).

3. Paul Schiff Berman, A Pluralist Approach to International Law, 32 YALE J. INT'L L. 301, 305 (2007). See generally OONA A. Hathaway \& HaROld HONGJU KoH, Foundations of INTERNATIONAL LAW AND POLITICS 173-204 (2005) (reviewing tenets of political realism).

4. Myres S. McDougal, International Law, Power and Policy: A Contemporary Conception, 82 RECUEIL DES COURS 137, 157 (1953).

5. W. Michael Reisman, International Lawmaking: A Process of Communication, 75 AM. SOC'Y INT'L L. PROC. 101, 113 (1981).

6. Id. at 107. 
than just a body of rules, the New Haven School committed itself not simply to a study of bare process, but more fundamentally, to an examination of a process of authoritative decisionmaking dedicated to promoting a set of normative values. As Michael wrote, the New Haven School insisted "that the end of law and the criterion for appraisal of particular decisions was their degree of contribution to the achievement of a public order of human dignity." 7 As an unusually courageous president of the Inter-American Commission on Human Rights and an international arbitrator of global renown, Michael insisted upon maintaining and building the School's connection between law and policy. The New Haven School became known as a school of policy-oriented jurisprudence, in no small part because of Michael's conviction that international law rules are intended to reflect the needs of international policy arguments. ${ }^{8}$

Second, Michael is an outstanding teacher. No one has had more time for his students, and he has personally guided and inspired a generation of scholars and teachers, as evidenced by the large group gathered here today. Michael helped give birth to the Yale Journal of International Law, which fittingly publishes these conference proceedings in his honor. As Michael himself recalled, the then-Dean of Yale Law School actually rejected the original student proposal to form a journal of international law in 1974. But undaunted, with Michael's support, the determined organizers insisted upon founding and publishing the journal anyway, working "[i]n secrecy, in the bowels of the international law library ... at night ... [in] an underground bunker," using half of the graduate stipend of the first Editor-in-Chief to print the journal from 1974 to $1978 .^{9}$

A third reason to celebrate Michael is for the remarkable mentor and role model he has been. During the quarter century that we have been together on the Yale faculty, Michael and his remarkable wife Mahnoush Arsanjanian extraordinary international lawyer and scholar in her own right-have shown me the kind of graciousness and warmth that young international law professors can only dream of. I remember seeing them at a conference in Boston twenty years ago, which ended with their graciously giving me a ride all the way home (and giving me priceless advice along the way). On a few occasions, although we have rarely had time to lunch together in New Haven, we have shared meals together in Washington, D.C. or some foreign capital. But for me, the most memorable moments have been beautiful dinners at their home in North Haven, where amid the birch trees and wooded hills, my wife Christy and I have found ourselves breaking bread with international law figures I had always wanted to meet-ambassadors, international jurists, legal advisers-all of whom Michael and Mahnoush had lured briefly away from

7. W. Michael Reisman, Theory About Law: Jurisprudence for a Free Society, 108 YALE L.J. 939 (1999).

8. See, e.g., Myres S. McDougal \& W. Michael Reisman, International Law in Policy-

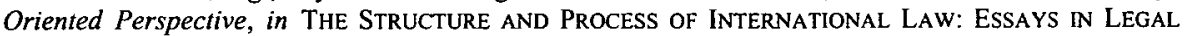
PHILOSOPHY, DOCTRINE AND THEORY (Ronald St. J. MacDonald \& Douglas Johnston eds., 1983).

9. W. Michael Reisman, The Vision and Mission of The Yale Joumal of International Law, 25 YALE J. INT'L L. 263, 264 (2000). 
New York City and the United Nations to become visiting students of the New Haven School of International Law.

The fourth, final, and most important point to recognize about Michael Reisman is that he is only in mid-career. His astonishing output continues unabated, his energy puts his younger colleagues to shame, and his zest to write and engage in the world of international action and ideas has never been greater.

So we come here today not just to honor Michael Reisman, the Dean of the New Haven School of International Law. We also take stock of a lifetime of work that is still very much in progress: the accomplishments of a scholar, teacher, mentor, and colleague who could say, to paraphrase John Paul Jones, "I have only just begun to write!" And, I would add, he has only just begun to influence the intellectual framers of a new global century that, after all, is only just beginning. 